\title{
Preparation and Evaluation of Floating Microspheres of Cefdinir in Treatment of Otitis Media and Respiratory Tract Infections
}

\author{
Anjali Devi N*, Vijendar C, Anil Goud K, Anil Kumar D, Khaja M and Anil A \\ Department of Pharmaceutics, University College of Pharmaceutical Sciences, Kakatiya University, Warangal 506009, Telangana, India
}

\begin{abstract}
The main objective of the present investigation was to develop gastro retentive (floating) microsphere for Cefdinir. Cefdinir, Third-generation bactericidal cephalosporin antibiotic drugs has been chosen as a model drug in the formulation of floating drug delivery systems. It is a drug of choice in treatment of otitis media, soft tissue infections, and respiratory tract infections, including sinusitis, strep throat, community-acquired pneumonia and acute exacerbations of bronchitis. Three biocompatible polymers like HPMC, Ethyl cellulose and Eudragit were chosen in varying proportions with the drug. F5 formulation with drug: polymer (1:2) show excellent micromeritic properties, percent yield (87.22\%), drug entrapment efficiency $(92 \%)$, percent buoyancy $(89 \%)$, and highest invitro drug release $98.9 \%$ within $12 \mathrm{~h}$. In the stability studies no significant change in drug entrapment release characteristics of the microspheres.
\end{abstract}

Keywords: Cefdinir; Floating microspheres; Buoyancy; Hydroxy propyl methyl cellulose

\section{Introduction}

Comprehensive knowledge about GI dynamics such as gastric emptying, small intestine transit, colonic transit, etc. is the key for designing oral controlled release dosage forms. The rate and extent of drug absorption from different sites of GI tract and factors that govern the absorption further assist the design of dosage form.

\section{Materials and methods}

\section{Materials}

Cefdinir is a gift sample from Chandra labs, Hyderabad, India. Hydroxy propyl methyl cellulose, Ethyl cellulose, poly vinyl alcohol and Eudragit s100 are purchased from SD Fine Chemicals Ltd, Mumbai, India.

\section{Methods}

Preparation of floating microspheres of cefdinir: Floating microspheres were prepared by the solvent evaporation method. Various concentration of polymer in suitable solvents were mixed well with the Cefdinir in different ratios of polymer and this pasty mass was introduced into $50 \mathrm{ml}$ of aqueous saline phase containing $0.04 \%$ (20 $\mathrm{mg}$ ) polyvinyl alcohol (PVA) and $10 \%(5 \mathrm{ml})$ ethanol. The system was stirred using Propeller at $300 \mathrm{rpm}$ at room temperature for $2-3 \mathrm{~h}$. The drug loaded floating microspheres formed were filtered, washed and dried in a hot air oven at $60^{\circ} \mathrm{C}$ (Table 1$)$.

\begin{tabular}{|c|c|c|c|c|c|c|c|c|c|}
\hline Ingredients(mg) & F1 & F2 & F3 & F4 & F5 & F6 & F7 & F8 & F9 \\
\hline Cefdinir & 600 & 600 & 600 & 600 & 600 & 600 & 600 & 600 & 600 \\
\hline HPMC & 600 & 1200 & 1800 & - & - & - & - & - & - \\
\hline Eudragit S100 & - & - & - & 600 & 1200 & 1800 & - & - & - \\
\hline Ethyl cellulose & - & - & - & - & - & - & 600 & 1200 & 1800 \\
\hline NaHCO & 600 & 1200 & 1800 & 600 & 1200 & 1800 & 600 & 1200 & 1800 \\
\hline Water (ml) & Q.S & Q.S & Q.S & - & - & - & - & - & - \\
\hline $\begin{array}{c}\text { Dichloromethane: } \\
\text { Ethanol } \\
(2: 1)(m l)\end{array}$ & - & - & - & Q.S & Q.S & Q.s & - & - & - \\
\hline Ethanol (ml) & - & - & - & - & - & - & Q.S & Q.S & Q.s \\
\hline
\end{tabular}

Table1: Formulation of cefdinir floating microspheres.
Drug-excipient compatibility study: Prior to the development of the dosage forms the preformulation study was carried out. FTIR spectra were recorded with a Thermo Nicolet, Japan. In the range 400$4000 \mathrm{~cm}^{-1}$ using a resolution of $4 \mathrm{~cm}^{-1}$ and 16 scans. Samples were diluted with kbr mixing powder, and pressed to obtain self-supporting disks. Liquid samples formulations were analyzed to form a thin liquid film between two kbr disks.

\section{Evaluation of Floating Microspheres}

\section{Micromeritic studies}

The prepared microspheres are characterized by their micromeritic properties, such as microsphere size, tapped density, Carr's compressibility index, Hausner's ratio and angle of repose (Table 2).

\section{In vitro buoyancy studies}

The in vitro buoyancy was determined by floating lag time, and total floating time. The microspheres were placed in a $100 \mathrm{ml}$ beaker containing $0.1 \mathrm{~N} \mathrm{HCl}$. The time required for the microspheres to rise to the surface and float was determined as floating lag time (FLT) and the duration of the time the microspheres constantly float on the dissolution medium was noted as the total floating time respectively (TFT) [1-3].

$$
\text { \%Buoyancy }=\mathrm{Q}_{\mathrm{f}} /\left(\mathrm{Q}_{\mathrm{f}}+\mathrm{Q}_{\mathrm{s}}\right) \mathrm{X} 100
$$

Where $Q_{f}$ and $Q_{s}$ are the weight of the floating and settled microspheres respectively.

*Corresponding author: Anjali Devi N, Department of Pharmaceutics, University College of Pharmaceutical Sciences, Kakatiya University, Warangal 506009, Telangana, India, Tel: 9701142628; E-mail: anjali_nippani@yahoo.com

Received: March 22, 2016; Accepted May 21, 2016; Published May 26, 2016

Citation: Devi AN, Vijendar C, Goud AK, Kumar AD, Khaja M, et al. (2016) Preparation and Evaluation of Floating Microspheres of Cefdinir in Treatment of Otitis Media and Respiratory Tract Infections. J Pharmacovigilance 4: 209. doi:10.4172/2329-6887.1000209

Copyright: ( 2016 Devi AN, et al. This is an open-access article distributed under the terms of the Creative Commons Attribution License, which permits unrestricted use, distribution, and reproduction in any medium, provided the original author and source are credited. 
Citation: Devi AN, Vijendar C, Goud AK, Kumar AD, Khaja M, et al. (2016) Preparation and Evaluation of Floating Microspheres of Cefdinir in Treatment of Otitis Media and Respiratory Tract Infections. J Pharmacovigilance 4: 209. doi:10.4172/2329-6887.1000209

Page 2 of 4

\section{Swelling index studies}

The swelling behaviour of a dosage unit was measured by studying its weight gain. The swelling index of microspheres was determined by placing the microspheres in the basket of dissolution apparatus using dissolution medium $0.1 \mathrm{~N} \mathrm{HCl}$ at $37 \pm 0.5^{\circ} \mathrm{C}$. After $0.5,1,2,3,4,5$, and $6 \mathrm{~h}$, each dissolution basket containing microspheres was withdrawn, blotted with tissue paper to remove the excess water and weighed on the analytical balance (Schimdzu, AX 120). Swelling index was calculated by using the following formula $[4,5]$.

$$
\text { Swelling index }=\frac{(\text { Wet weight of microspheres }- \text { Dry weight of microspheres })}{\text { Dry weight of microspheres }}
$$

\section{Drug entrapment efficiency}

The amount of drug entrapped was estimated by crushing the microspheres and extracting with aliquots of $0.1 \mathrm{~N} \mathrm{HCl}(\mathrm{pH}-1.2)$ repeatedly $[6,7]$. The extract was transferred to a $100 \mathrm{ml}$ volumetric flask and the volume was made up using $0.1 \mathrm{~N} \mathrm{HCl}(\mathrm{pH}-1.2)$. The solution was filtered and the absorbance was measured after suitable dilution spectrophotometrically (UV 1700, Shimadzu, Japan) at $220 \mathrm{~nm}$ against appropriate blank (Table 3).

$$
\text { Drug entrapment efficiency }(\%)=\frac{\text { Amount of drug actually present } \times 100}{\text { Theoretical drug load expected }}
$$

\section{In-vitro release study}

The drug release study was performed for microsphere containing quantity equivalent to $300 \mathrm{mg}$ of Cefdinir by using USP dissolution apparatus Type I in $900 \mathrm{ml}$ of $0.1 \mathrm{~N} \mathrm{HCl}$ dissolution media (pH-1.2) at $100 \mathrm{rpm}$ and $37^{\circ} \mathrm{C}$ temperature. $10 \mathrm{ml}$ of sample was withdrawn at predetermined time interval for 12 hours and same volume of fresh medium was replaced to maintained sink condition. Withdrawn samples were assayed spectrophotometrically at $220 \mathrm{~nm}$. Drug release was also performed for pure drug (Table 4) [8-10].

\begin{tabular}{|c|c|c|c|c|c|}
\hline Formulation & $\begin{array}{c}\text { Bulk } \\
\text { density }\end{array}$ & $\begin{array}{c}\text { Tapped } \\
\text { density }\end{array}$ & $\begin{array}{c}\text { Carr's } \\
\text { index }\end{array}$ & $\begin{array}{c}\text { Hausner's } \\
\text { ratio }\end{array}$ & $\begin{array}{c}\text { Angle of } \\
\text { repose }\end{array}$ \\
\hline F5 & 0.44 & 0.52 & 15.48 & 1.18 & 28.52 \\
\hline
\end{tabular}

Table 2: Micro particulate analysis.

\begin{tabular}{|c|c|c|c|c|c|c|c|}
\hline S.No & $\begin{array}{c}\text { Formulation } \\
\text { code }\end{array}$ & $\begin{array}{c}\% \\
\text { Yield }\end{array}$ & $\begin{array}{c}\% \\
\text { Buoyancy }\end{array}$ & $\begin{array}{c}\% \text { Drug } \\
\text { entrapment } \\
\text { efficiency }\end{array}$ & $\begin{array}{c}\text { \%Swelling } \\
\text { Index }\end{array}$ & $\begin{array}{c}\text { Lag } \\
\text { time }\end{array}$ & $\begin{array}{c}\text { Floating } \\
\text { time }\end{array}$ \\
\hline 1 & F1 & 80 & 63 & 62.66 & 33.32 & $12 \mathrm{~m}$ & $8 \mathrm{~h}$ \\
\hline 2 & F2 & 83.33 & 67 & 72 & 35.66 & $10 \mathrm{~m}$ & $8 \mathrm{~h}$ \\
\hline 3 & F3 & 85 & 75 & 89 & 30.91 & $7 \mathrm{~m}$ & $8 \mathrm{~h}$ \\
\hline 4 & F4 & 86 & 79 & 56 & 32.33 & $6 \mathrm{~m}$ & $10 \mathrm{~h}$ \\
\hline 5 & F5 & 87.22 & 89 & 92 & 38.11 & $3 \mathrm{~m}$ & $>12 \mathrm{~h}$ \\
\hline 6 & F6 & 80 & 85 & 72 & 38.18 & $3 \mathrm{~m}$ & $>12 \mathrm{~h}$ \\
\hline 7 & F7 & 88 & 70 & 80 & 36.55 & $7 \mathrm{~m}$ & $10 \mathrm{~h}$ \\
\hline 8 & F8 & 82 & 76 & 82 & 37.32 & $8 \mathrm{~m}$ & $10 \mathrm{~h}$ \\
\hline 9 & F9 & 80 & 84 & 67 & 35.66 & $4 \mathrm{~m}$ & $>12 \mathrm{~h}$ \\
\hline
\end{tabular}

Table 3: Percentage yield and percentage drug entrapment efficiency of the

\begin{tabular}{|c|c|c|c|c|}
\hline \multicolumn{5}{|c|}{ Release Kinetics } \\
\hline & ZERO & HIGUCHI & PEPPAS & FIRST \\
\hline & 1 & 2 & 3 & 4 \\
\hline & Q Vs T & $Q V s \sqrt{ } T$ & $\log C V s \log T$ & $\begin{array}{c}\log \% \text { Remain } \\
\text { Vs T }\end{array}$ \\
\hline Slope(n) & 6.85 & 24.73 & 1.18 & -0.06 \\
\hline $\mathrm{R} 2$ & 0.9850 & 0.9365 & 0.69 & 0.91 \\
\hline
\end{tabular}
prepared microspheres.
Table 4: In vitro drug release kinetics data for Formulation F5.

\section{Release kinetics}

The matrix systems were reported to follow the Pappas release rate and the diffusion mechanism for the release of the drug [11-14]. To analyse the mechanism for the release and release rate kinetics of the dosage form, the data obtained fitted, Zero order, First order, Higuchi matrix, Pappas and Hixson Crowell model. By comparing the r-values obtained, the best-fit model was selected.

\section{Stability studies}

Stability of a drug has been defined as the ability of a particular formulation, in a specific container, to remain within its physical, chemical, therapeutic and toxicological specifications. The purpose of stability testing is to provide evidence on how the quality of a drug substance or drug product varies with time under the influence of a variety of environmental factors such as temperature, humidity, light, and enables recommended storage conditions $[6,15]$.

\section{Results and Discussion}

\section{Compatibility studies}

Drug polymer compatibility studies were carried out using Fourier Transform Infra Red spectroscopy to establish any possible interaction of Cefdinir with the polymers used in the formulation [16,17]. The FTIR spectra of the formulations were compared with the FTIR spectra of the pure drug (Figures 1 and 2).

\section{Pre-formulation parameters}

Optimized formulation for bulk density, tapped density, \% compressibility, hausner's ratio and angle of repose. The results of \% compressibility, hausner's ratio and angle of repose were found to be $<16,<1.25$ and $<30$ respectively.

\section{Evaluation of Microspheres}

\section{Percentage yield}

It was observed that as the polymer ratio in the formulation increases, the product yield also increases. The percentage yield of optimized formulation (F5) is $87.22 \%$.

\section{Drug entrapment efficiency}

Percentage Drug entrapment efficiency of cefdinir arranged from 62 to $89 \%$ for microspheres containing HPMC as polymer, 56 to $92 \%$ for microspheres containing Eudragit S 100 as polymer and 67 to $82 \%$ for microspheres contains Ethyl cellulose as polymer. F5 formulation shows $92 \%$ of entrapment efficiency.

\section{In-vitro drug release studies}

Dissolution studies of all the formulations were carried out using dissolution apparatus. The dissolution studies were conducted 


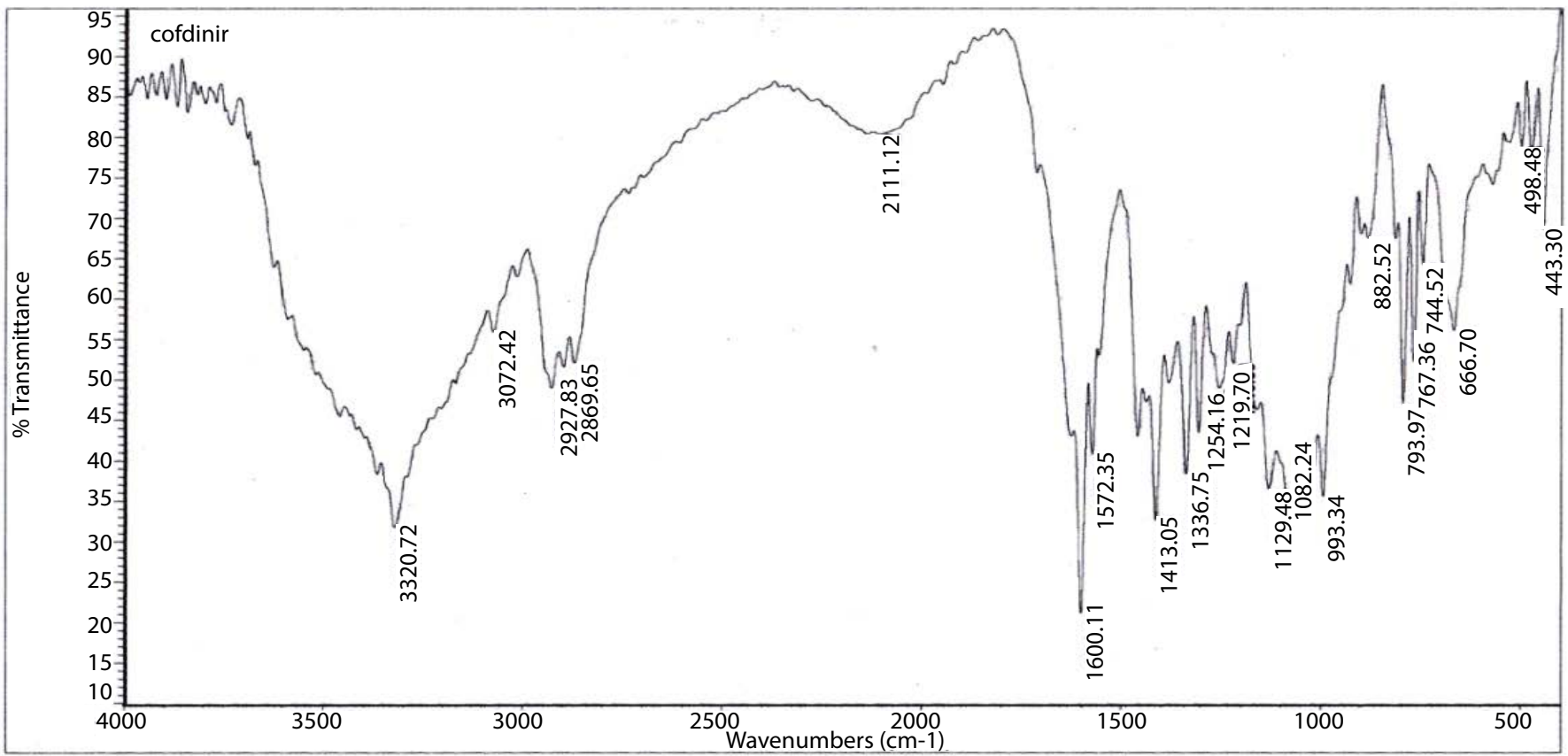

Figure 1: FTIR Spectra of pure drug.

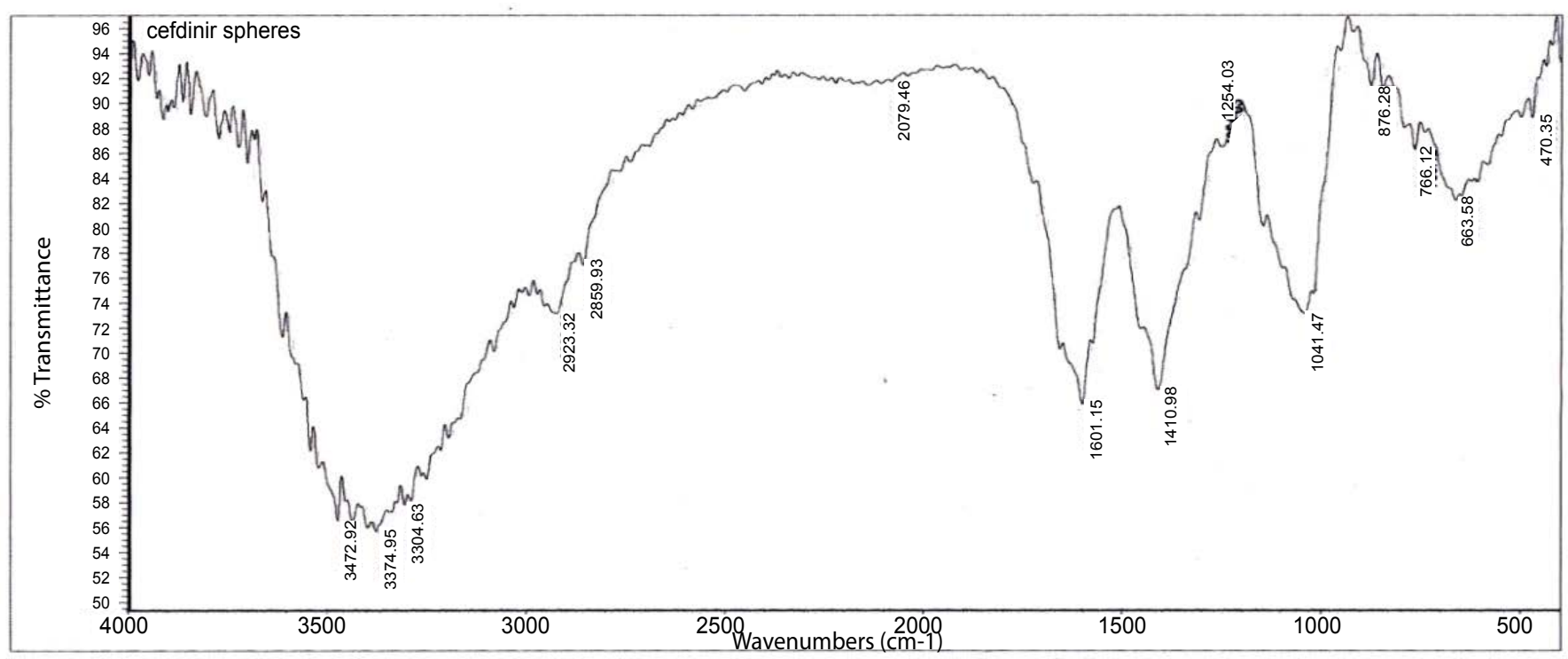

Figure 2: FTIR spectra of optimized formulation.

by using dissolution media, $\mathrm{pH}$ 1.2. The plots of Cumulative percentage drug release vs Time. F5 formulation shown signficant release $98.95 \%$ within $12 \mathrm{~h}$ (Figure 3 ).

\section{In-vitro drug release kinetics}

The in-vitro drug dissolution data obtained was fitted to various mathematical

Models such as zero order, First order, Higuchi matrix, and KrosmeyerPeppas model. The kinetic data analysis of all the formulations reached higher coefficient of determination with the Zero order $\left(R^{2}=0.985\right)$.

\section{Stability studies of cefdinir optimized formulation}

The optimized formulation of Cefdinir (F5) was subjected to shortterm stability testing by storing the microspheres at room temperature $25^{\circ} \mathrm{C} / 60 \% \mathrm{RH}$ and also subjected to accelerated stability testing by storing the microspheres at temperature $40^{\circ} \mathrm{C} / 70 \% \mathrm{RH}$.

\section{Conclusion}

The present study has been a satisfactory attempt to formulate floating microspheres of cefdinir with a view of improving its oral bioavailability and giving a controlled release of the drug. The floating 
Citation: Devi AN, Vijendar C, Goud AK, Kumar AD, Khaja M, et al. (2016) Preparation and Evaluation of Floating Microspheres of Cefdinir in Treatment of Otitis Media and Respiratory Tract Infections. J Pharmacovigilance 4: 209. doi:10.4172/2329-6887.1000209

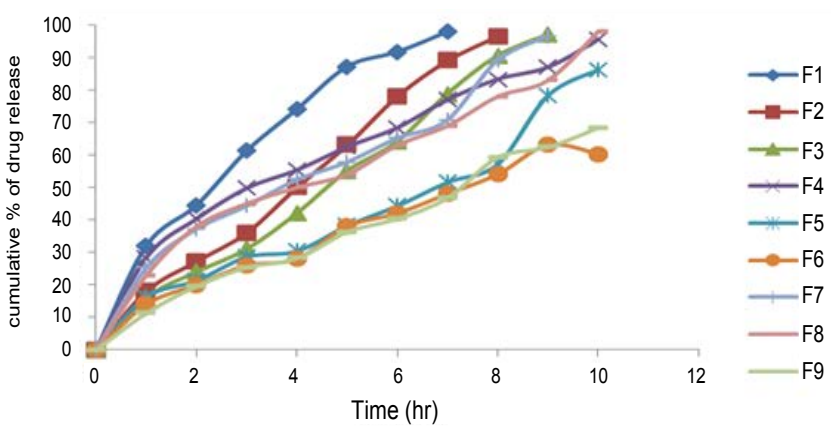

Figure 3: In vitro release profile of F1 -F9 formulations.

microspheres of drug with HPMC and Ethyl cellulose were buoyant while those with Eudragit S 100 showed greater buoyancy (89\%) percent yield (87.22\%), drug entrapment efficiency (92\%), and highest invitro drug release $98.9 \%$ within 12 hours. The formulations f5best fitted into zero order. Microspheres were stable and compatible at the room and temperature and humidity in storage for 90 days. In stability studies no significant change in the drug entrapment, release characteristics of the microspheres.

\section{References}

1. Brahmaiah B, Bhagath GP, Gudipati M (2013) Formulation and evaluation of Gastroretentive floating drug delivery system of metoprolol tartarate. International Journal of Life Sciences Biotechnology and Pharma Research 2.

2. Baumgastner S, Kristal J, Vreer F, Vodopivec P, Zorko B (2000) Optimisation of Floating matrix tablet and evaluation of their gastric residence time. Int $\mathrm{J}$ Pharm 195: 125-135

3. Ramu S, Suresh P, Srinivasa Rao D (2015) Formulation and evaluation of floating microspheres of rosiglitazone. IJPCBS 5: 907-918.

4. Balamurugan J, vijayalakshmi $P$ (2014) Preparation and evaluation of floating extended release matrix tablet using combination of polymethacrylates and polyethylene oxide polymers. International Journal of Pharmacy and Pharmaceutical Sciences 6: 8.

5. Kagan L, Hoffman A (2008) Selection of drug candidates for gastroretentive dosage forms: Pharmacokinetics following continuous intragastric mode of administration in a rat model. Eur J Pharm Biopharm 69: 238-246.
6. Prakash K, Sriram N (2012) Formulation and evaluation of mucoadhesive microspheres of pioglitazone hydrochloride prepared by solvent evaporation technique. International Journal of Biological \& Pharmaceutical Research 3 . 1005-1015.

7. Dr.Jose,G.R, Hossein,C.,Khalid,S.2003. Progresses in gastro retentive drug delivery system, Business Briefling Pharmatech.1-4. Http://www. touchbriefings.com.

8. Yeole PG, Shagufta K, Patel VF (2005) Floating drug delivery system need and development. Ind J pharma 67: 256-272.

9. Ramdas TD, Avinash H, Anil B, Brijesh K, Sachin S (2011) Novel Sustained Release gastroretentive Drug Delivery System: A Review. IJPRD 2: 26-41.

10. KD Tripathi (2008) Essentials of Medical Pharmacology, $6^{\text {th }}$ (edn).

11. Dash S, Murthy PN, Nath L, Chowdhury P (2010) Kinetic modeling on drug release from controlled drug delivery systems. Acta Pol Pharm 67: 217-223.

12. Desai JU, Parikh JR, Parikh RH (2007) Floating Drug Delivery Systems: An Approach To Gastro Retention. Pharma Info Net 7: 5.

13. Kone PR, Saudagar RB, Daharwal SJ (2007) Gastro-Retentive Drugs: A Novel Approach towards Floating Therapy. Pharma Info Net 5.

14. Nayak AK, Maji R, Das B (2010) Gastroretentive drug delivery systems: a review. Asian J Pharm Clin Res 3: 1-10.

15. Rani SB, Hari VBN, Reddy BA, Punitha S, Devi P, et al. (2010) The recent developments on gastric floating Drug delivery systems: an overview. Int $\mathrm{J}$ Pharm Tech Res 2: 524-534.

16. Mostafavi A, Emami J, Varshosaz J, Davies NM, Rezazadeh M (2011) Development of a prolonged-release gastroretentive tablet formulation of ciprofloxacin hydrochloride: pharmacokinetic characterization in healthy human volunteers. Int J Pharm 409: 128-136.

17. Sauzet C, Claeys-Bruno M, Nicolas M, Kister J, Piccerelle P, et al. (2009) An innovative floating gastro retentive dosage system: formulation and in vitro evaluation. Int J Pharm 378: 23-29.

18. Chavanpatil M, Jain P, Chaudhari S, Shear R, Vavia P (2005) Development of sustained release gastroretentive drug delivery system for ofloxacin: in vitro and in vivo evaluation. Int J Pharm 304: 178-184.

19. Dave BS, Amin AF, Patel MM (2004) Gastroretentive drug delivery system of ranitidine hydrochloride: formulation and in vitro evaluation. AAPS PharmSciTech 5: e34.

20. Dave BS, Amin AF, Patel MM (2004) Gastroretentive drug delivery system of ranitidine hydrochloride: formulation and in vitro evaluation. AAPS PharmSciTech 5: e34. 